Maciej Nowak

Ośrodek Badań nad Literaturą Religijną,

Katolicki Uniwersytet Lubelski Jana Pawła II

\title{
Decydujący moment. Wokół biografii Andrzeja Bobkowskiego
}

W pierwszej części tekstu przedstawiam zagadnienia uznane przeze mnie za ważne w pracy każdego biografa. Mają one charakter ogólny, choć odwołuję się do ustaleń i rozwiązań, które pojawiły się u mnie w związku z badaniem losów konkretnej postaci. Zwracam zatem uwagę, że są to obserwacje raczej praktyka niż teoretyka biografii - autora ciągle jeszcze pochylonego nad powstającą książką. W drugiej części prezentuję fragment biografii Andrzeja Bobkowskiego; w moim zamyśle stanowi on realizację tytułowego konceptu decydującego momentu.

1.

Pracy nad biografią towarzyszą problemy permanentnie albo tylko marginesowo - bądź w innym kontekście - pojawiające się na drodze, którą kroczy historyk literatury. Należą do nich kontakty osobiste z opiekunami prywatnych archiwów, członkami rodziny, świadkami epoki. Biograf, prowadząc swoje badania, do których zaliczam również „wizje lokalne” w miejscach pobytu bohatera opracowania, co jakiś czas przekonuje się o tym, że kro- 
czy po śladach żywej osoby. I jak udowadnia to w swych książkach Richard Holmes [2011; 2017], autor świetnie przyjmowanych biografii z epoki romantyzmu, nie ma tu znaczenia ilość czasu, jaka upłynęła od śmierci portretowanej postaci. Angielski badacz w pysznych anegdotach uświadamia czytelnikom wagę kontaktu z osobami bezpośrednio odpowiedzialnymi za dostęp do takiego lub innego miejsca' ${ }^{1}$ Przekonująco także argumentuje za traktowaniem konkretnego terytorium jako „źródła” - określa je mianem informative place - służącego budowaniu biograficznego kontekstu dla twórczości.

Biograf nie rekonstruuje zatem na drodze „czystej” intelektualnej spekulacji etycznych przekonań autora Punktu równowagi, tylko snuje „zmącone” rozważania nad postępowaniem mężczyzny, który z 14 na 15 kwietnia 1961 roku - zatajając to przed żoną wynajął pokój w Hotelu Regent u zbiegu Broadway’u i 104. ulicy w Nowym Jorku². Choć sprawę trzeba przedstawić inaczej - biograf starający się ujrzeć w swoim bohaterze integralnie rozumianą osobę, rozpatrując kwestię nocy spędzonej w pokoju 716, cały czas pamięta o tym, iż mężczyzna ukrywający ten fakt przed żoną był także autorem tekstów skłaniających do interpretacji filozoficznych. Podejmując tę myśl, portretujemy Bobkowskiego zarówno jako dżentelmena w skrytości wynajmującego pokój za 6 dolarów plus podatek (3o centów), jak i - w tym kontekście - autora prozy opowiadającej o romansie Gilberta i Eleny, postaci z opowiadania Spotkanie. Chcę przez to powiedzieć, że kompetencje biografa „integralnego” powinny wykraczać poza znajomość faktów z kalendarium i obejmować rozumienie tej dziedziny kultury, dzięki której jego bohater przeszedł $\mathrm{z}$ domeny prywatnej w publiczną ${ }^{3}$.

1 Zob. choćby opowieść o wizycie w Greta Hall (Keswik), w domu niegdyś zamieszkiwanym przez Samuela Taylora Coleridge’a, a obecnie zajmowanym przez szkołę z internatem dla dziewcząt [Holmes 2017: 13-14]. Obecnie - w październiku 2019 roku - w tym samym, oddanym do użytku w 1923 roku budynku, należącym do miasta i noszącym nazwę Regent Family Residence, organizacja Volunteers of America prowadzi rodzaj schroniska dla stu czterdziestu rodzin. Budynek zachował jednak swą integralność i charakterystyczny dla szkoły Beaux Arts wystrój, który mógł podziwiać Bobkowski [Grey 2003]. 


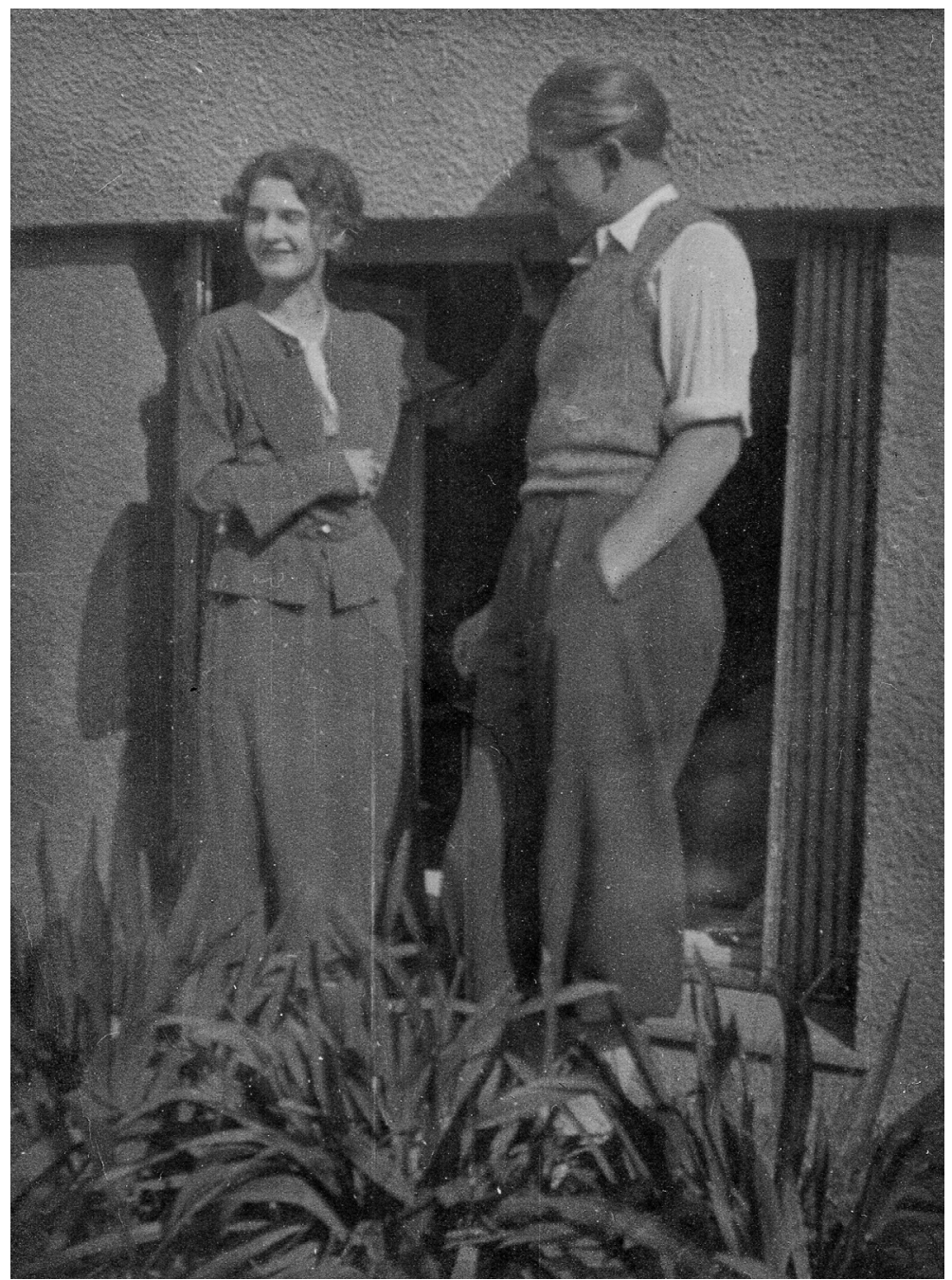

Ryc. 1 Barbara Birtusówna i Andrzej Bobkowski, okres narzeczeński Warszawa, wrzesień 1936 roku (fot. ze zbiorów Muzeum Literatury im. Adama Mickiewicza w Warszawie) 


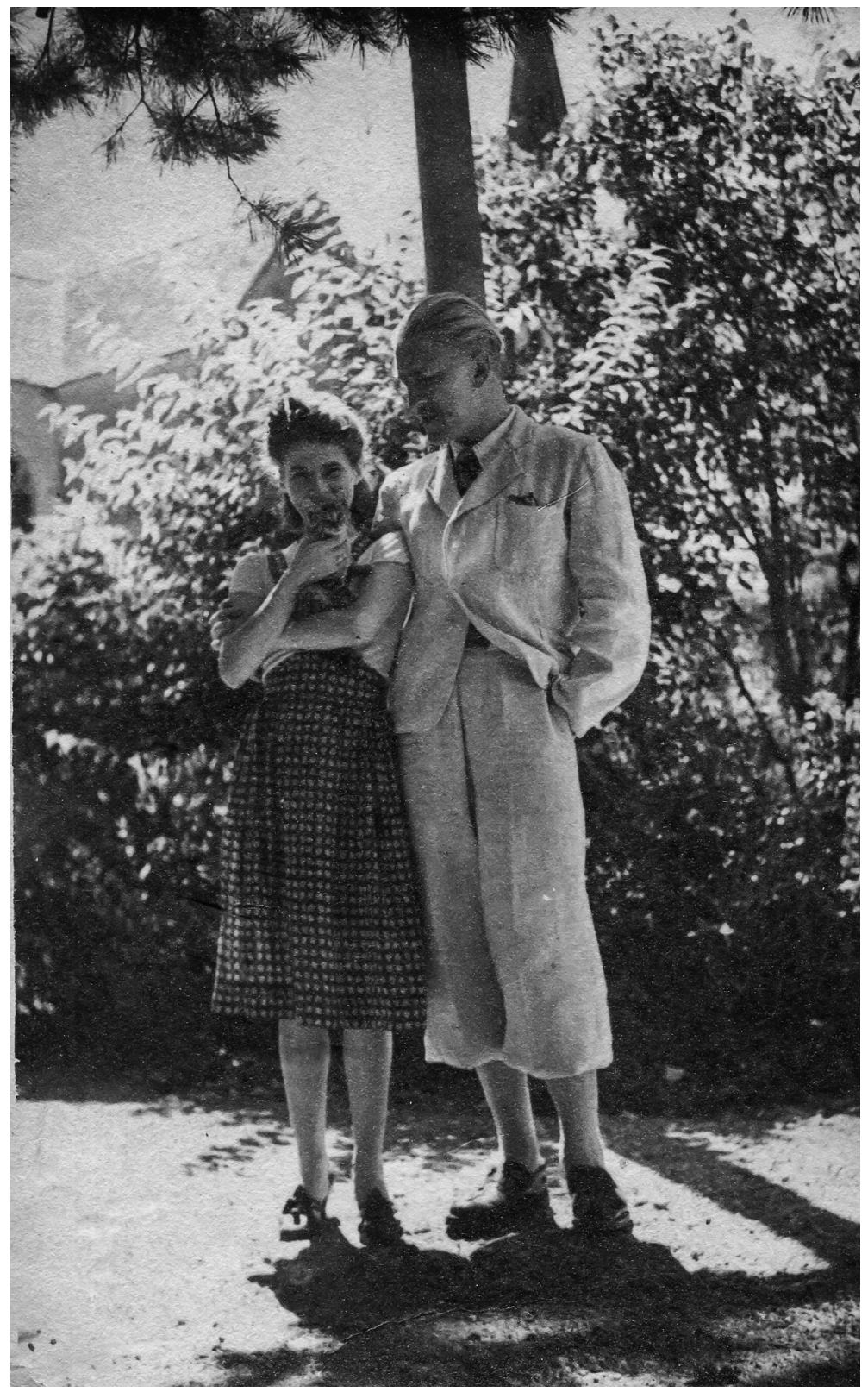

Ryc. 2 Barbara i Andrzej Bobkowscy parę tygodni po wyjeździe z Polski - Paryż 1939 rok (fot. ze zbiorów Muzeum Literatury im. Adama Mickiewicza w Warszawie) 
W przypadku Bobkowskiego zadecydowało o tym pisarstwo. Czymś charakterystycznym dla tej jego aktywności było twórcze przenoszenie gatunków „prywatnych” w domenę publiczną. Debiutował w roku 1935 humoreską $W$ parku frakowym, napisaną w konwencji „kartki z dziennika” [Bobkowski 1935: 3]. Po wojnie ogłaszał różnego rodzaju dzienniki okresowe, a najobszerniejszemu z nich - Szkicom piórkiem - zawdzięcza trwałe miejsce w dziejach polskiej literatury nowoczesnej. Przypomnę, że drugiej części głośnego w swoim czasie dyptyku ${ }^{4}$, poświęconego aksjologicznemu uzasadnieniu emigracji, autor nadał postać korespondencji z przyjacielem, który wrócił z Zachodu do kraju. A jednak Bobkowski do śmierci nie opublikował żadnego wcześniej nieopracowanego fragmentu dziennika ani autentycznego listu, choć

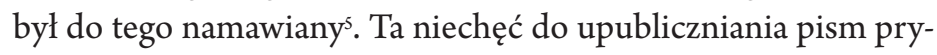
watnych wskazuje na wyostrzoną u niego świadomość istnienia różnych autonomicznych sfer i wymiarów życia wraz z odmiennymi zasadami, które nimi rządzą. Już w młodzieńczym dzienniku, odnosząc się do krytycznej uwagi rzuconej przez ojca, zanotowat: „No to odpowiedziałem, że ma się zwykle dwie natury - jedną dla ludzi, a drugą dla siebie, ewentualnie, w drodze wielkiej łaski, dla kogoś, ale jednego" [Bobkowski 1932]. W świetle późniejszych losów, decyzji i wyborów, zarówno tych w życiu osobistym, jak i tych pisarskich, wyznanie dziewiętnastolatka wprost uderza trafnością (auto)analizy. Przyjęcie założenia o integralnym charakterze przedmiotu dociekań biografa - osoby w pełnym wachlarzu spełnianych przez nią funkcji i stron osobowości - umożliwia dostrzeżenie w niej raczej ciągłości niż pęknięć. Tym samym chciałbym podkreślić swoje uznanie dla tego nurtu biografistyki, w którym próbuje się uchwycić wzajemne relacje między wydarzeniami i ich okolicznościami a sferą dokonań bohatera opowieści. Niestety, nie jest to nurt szeroki, najczęściej otrzymujemy bowiem opracowania niewykraczające poza „wydarzeniową” materię życia. 1948a].

5 Niemniej jeden raz zrobiono to wbrew niemu [Bobkowski 1950: 6]. 
Wracając do tematu sytuacji biografii i biografa, trudno sobie wyobrazić, aby autor hipotetycznej rozprawy poświęconej ewolucji metaforyki niedawno zmarłej poetki czy poety w swych badaniach był zależny od woli i nastrojów najbliższej rodziny twórcy. Praca badacza powinna fortunnie dobiec końca bez jakiegokolwiek kontaktu $\mathrm{z}$ tymi osobami. Prawdopodobnie nie musi on także obawiać się tego, że jakąś interpretacją wzbudzi niepokój wdowy lub krewnych. Natomiast autor biografii już na etapie gromadzenia informacji o miejscach przechowywania dokumentów spotyka się z problemem postawy osób posiadających wiedzę na ten temat, opiekujących się zbiorami'. Dostęp do cennych materiałów zależy od ich woli - chęci sprawowania kontroli nad dokumentami bądź całkowitej otwartości, ich podejrzliwości bądź zaufania. Podobnie dzieje się z odbiorem dzieła finalnego - opublikowanej biografii. Jej recepcja zdecydowanie różni się od odbioru rozprawy z zakresu poetyki historycznej.

Kilka lat temu obserwowaliśmy zamieszanie wywołane ukazaniem się biografii Ryszarda Kapuścińskiego pióra Artura Domosławskiego. Bardzo upraszczając, powiedzieć można, że Kapuściński non-fiction głęboko rozczarował wdowę po sławnym reporterze oraz grono znaczących postaci naszego życia publicznego. Powodem stało się ujawnienie przez biografa trojakiego rodzaju „nieprawidłowości”: intymnych, etycznych i warsztatowych. W świetle biografii pisarz okazywał się bowiem niewiernym małżonkiem, współpracownikiem komunistycznych tajnych służb oraz bardziej kompilatorem, a niekiedy i konfabulatorem, niż wiarygodnym świadkiem wydarzeń. Domosławski miał naruszyć nie tylko umowę z wdową - jak się zdaje, dopuszczenie do prywatnego archiwum Kapuścińskich było opatrzone pewnymi warunkami ale także jej dobra osobiste.

Ten przypadek uświadamia nam istnienie odrębnego „biograficznego" horyzontu oczekiwań czytelników. Rodzina, grono znajomych, środowisko i fani oczekują od autora biografii dzieła, mówiąc nieco żartobliwie, przenoszącego jego bohatera w sferę nieśmiertelności, oczekują pomnika, spodziewają się hołdu. Łączy

\footnotetext{
6 Barwnie opisał swe doświadczenia w tym zakresie James L. Clifford [1978].
} 
tych odbiorców jedno: chcą się zetknąć z wyjątkowym życiorysem, potwierdzającym wyjątkową pozycję, jaką zajęła portretowana osoba w dziedzinie, w której odniosła sukces.

Biografia ma więc innych odbiorców niż praca naukowa, a także inaczej jest czytana. Jej recepcji towarzyszy niegasnące zainteresowanie człowieka-czytelnika losem człowieka-bohatera-biografii. I nie mówię już o fanach i antyfanach, ale o bezstronnych klientach księgarń, szperających w dziale „biografie i wspomnienia" 7 .

W przypadku biografii autora Cesarza zakrawa na paradoks fakt, iż Domosławski nie przedstawiał wszystkich wymienionych przeze mnie „nieprawidłowości” jako uchybień. Na przykład współpraca Kapuścińskiego z tajnymi służbami znalazła uznanie w jego oczach. Jak widać, biografia narusza także pewne tabu. Być może w wypadku tej książki wrzawa wokół niej wywołana została także stosunkowo krótkim czasem, jaki dzielił śmierć jej bohatera od ukazania się poświęconej mu publikacji. Ta okoliczność, czas, jaki upływa od śmierci do rozpoczęcia pracy nad biografią i późniejszą jej prezentacją, ma znaczenie nie tylko materiałowe (liczba zachowanych dokumentów-śladów) czy warsztatowe (możliwość dotarcia do żyjących świadków wydarzeń), ale także prawne i moralne. Dziś już nikt nie zagrozi sądem autorowi ujawniającemu intymne szczegóły z życia Jana Kochanowskiego albo wyciągającemu na światło dzienne (hipotetyczne) nieprawidłowości w finansach Tadeusza Kościuszki. Wśród żywych nie ma ich krewnych i powinowatych, którzy mogliby zastraszać biografa, manipulować źródłami, ukrywać dokumenty, tak aby odpowiednio wplywać na jego pracę.

Mimo to pozostaje cały czas do rozstrzygnięcia problem etycznych ram pracy biografa. Zawężając temat, myślę o tym, czy biograf ma prawo, docierając do nieznanych dokumentów, a także przestrzegając wszelkich zasad badań archiwalnych, ujawniać nieciekawe, a czasami paskudne strony życiorysu. W pewnych okolicznościach nie wydają się one wyłącznie budzącymi nie-

7 Ira Bruce Nadel [1984: 155] tłumaczy popularność biografii zarówno u autorów, jak i czytelników jej „zdolnością do nadawania znaczenia życiu jednostki” oraz przekazywaniem „osobowości i charakteru poprzez [opowieść - M.N.] prozą”. 
zdrowe emocje "pikantnymi szczegółami”, ponieważ dają wgląd w osobowość, rzucają światło, poszerzają wiedzę, a niekiedy korygują zmitologizowany obraz ${ }^{8}$. Jestem przekonany, że biograf ma takie prawo, nawet sądzę, że zatrzymując tego rodzaju wiedzę dla siebie, dopuszcza się swego rodzaju manipulacji poprzez przemilczenie. Jako komentarz można przytoczyć pogląd Virginii Woolf [2015: 320] z jej znanego eseju: „Biografa wiążą fakty - tak jest; a skoro tak jest, to ma on prawo korzystać ze wszystkich faktów, jakie tylko są dostępne”.

Naturalnie cała rzecz musi się odbyć zgodnie z regułami sztuki biograficznej. I nie chodzi mi tu o specyficzny rodzaj biografii, nazwany nieco pogardliwie krytycznym czy odbrązawiającym. Każda rzetelna biografia znanej postaci ma w sobie potencjał odbrązawiający czy - jak ujmują to badacze anglosascy - korygujący [Hamilton 2017: 16-18]. Często prezentuje nieoficjalną, a bywa że nieświetną stronę wybitnej w jakiejś dziedzinie postaci, „weryfikuje fakty i szczegóły lub zastępuje legendę faktem” [Nadel 1984: 9]. W ten sposób ujawnia się ludzka strona osobowości, tkwiące w zwykłym życiu korzenie czegoś, co ową zwykłość przekracza - jak arcydzieła malarstwa, muzyki, poezji. Niczego w tej dziedzinie nie odkrywam. Jak przedstawia to Nigel Hamilton, początek nowoczesnej biografistyce dały poglądy Samuela Johnsona. Twierdził on, że

więcej wiedzy na temat prawdziwego charakteru człowieka można uzyskać z krótkiej rozmowy z jednym z jego służących, niż oficjalnej i wystudiowanej opowieści o nim, zaczynającej się od jego pochodzenia a kończącej się na pogrzebie. [Johnson 1750]

Także od Johnsona pochodzi myśl, iż zadaniem biografa nie jest sporządzanie kroniki życia i twórczości, lecz odsłonięcie moralnej istoty życia portretowanej postaci. W tak ukierunkowanej pracy oczywistym polem badań staje się życie prywatne.

8 "Jedna z ogromnych wad autoryzowanej [...] biografii Faulknera [pisze Paul Theroux - M.N.] pióra Josepha Blotnera polega na pominięciu romansów wielkiego pisarza (podczas gdy niektóre miały wielkie znaczenie dla jego kariery), a inną wadą jest bardzo ostrożne potraktowanie jego zdrad" [Theroux 2017: 281]. 


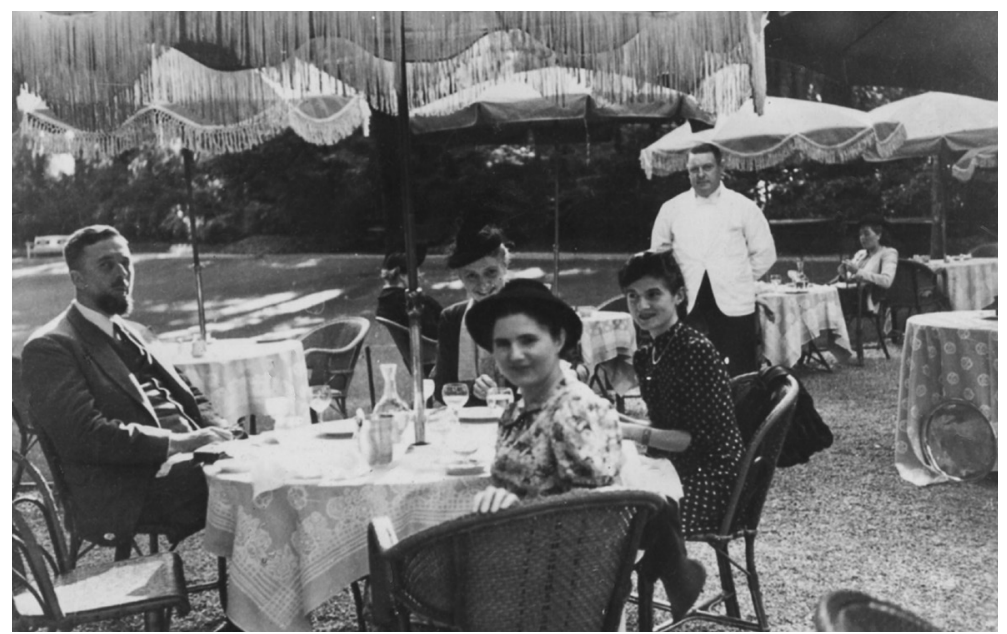

Ryc. 3 Od lewej do prawej: państwo Payen (przyjaciele rodziców Andrzeja Bobkowskiego), Maryna Birtusówna i jej siostra Barbara Bobkowska - Paryż, sierpień 1939 roku (fot. ze zbiorów prywatnych Małgorzaty Czerwińskiej-Miklaszewskiej)

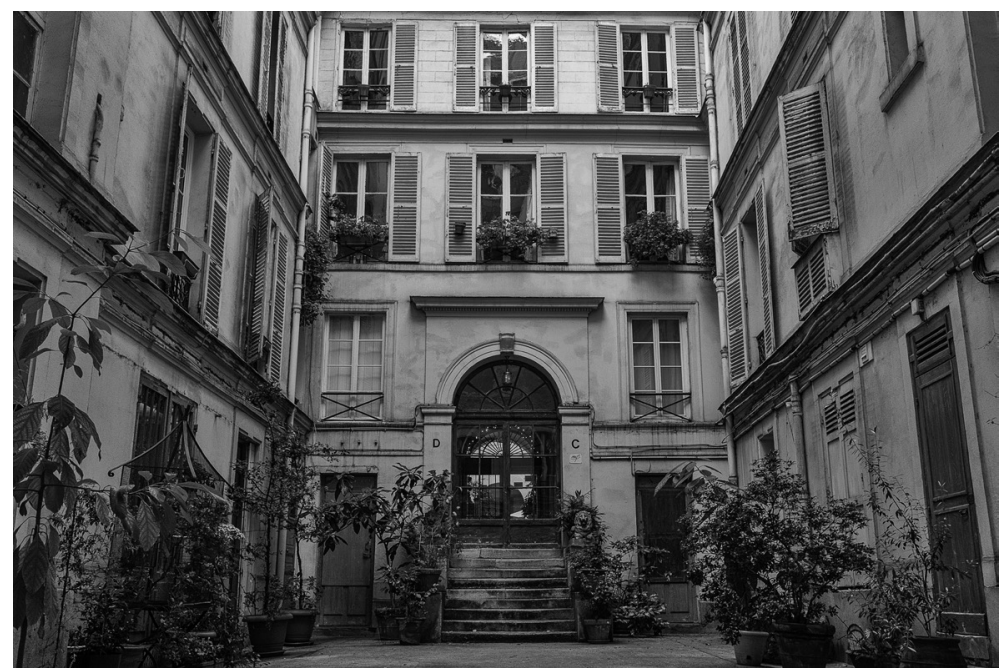

Ryc. 4 Dziedziniec kamienicy przy 20 Rue Saint Lazare, Bobkowscy mieszkali tu w mansardzie należącej do państwa Payen od 8 września 1939 roku do końca grudnia 1940 roku - Paryż, 2017 rok (fot. Maciej Nowak) 
Na biografię składa się więcej elementów niż ułożone chronologicznie zdarzenia - stanowią one (jedynie) fundament dla niefikcyjnej opowieści prozą. Jaj autor zawiera niepisany pakt z odbiorcą, polegający na zaufaniu, iż prezentowany materiał oparty został na weryfikowalnych faktach [Hoberman 2001: 109-110]. Biografia zdecydowanie nie przynależy zatem do literatury par excellence (fikcji) ${ }^{9}$. Oczywiście trud biografa polega m.in. na odpowiednim ułożeniu w całość tego, czego się dowiedział, ale przede wszystkim na przedstawieniu trajektorii życia bohatera opracowania. Zakłada to podjęcie wysiłku interpretacji faktów w celu zrekonstruowania hipotetycznej całości. Po przestrogach hermeneutyki, lekcji, jaką dała nam dekonstrukcja, i analizach Haydena White’a zabieramy się do tej pracy z wyostrzoną uwagą, czujni wobec pulapek fabularyzacji. Wiemy przy tym, iż niezależnie od tego, czy autor ma świadomość zagrożeń, czy nie, tworzona przez niego biografia nieuchronnie powstaje pod urokiem pewnego osobowego ideału i złożonych w języku wzorców opowieści ${ }^{10}$. Z jednej strony są one trybami pracy biografa, a z drugiej stylami odbioru jego dzieła. Część wysiłków w komponowaniu biografii powinna zatem kierować się ku utrzymywaniu krytycznej wrażliwości przez jej autora.

Rekonstrukcja trajektorii przypomina odsłanianie zasadniczej linii nadbudowującej się nad wydarzeniami składającymi się na kronikę. Kluczową rolę w tej pracy odgrywa wyznaczenie decydującego momentu biografii. To wycinek czasu wraz z okolicznościami, który rozstrzyga o tym, kim stanie się przedmiot badań - dla nas już się stał - w przyszłości. To moment decydujący, ponieważ po nim życie bohatera staje się zdecydowanie inne, nabiera innej dynamiki, zaczyna biec w innym kierunku. Jaki to kierunek? Ten decydujący o przejściu osoby z domeny prywatnej w domenę publiczną. Może to być pisarstwo, nauka, polityka... Ten moment - zdarzenie, decyzja, okoliczności - nie sprowadza

9 „Biografistyka to coś pomiędzy literaturą a dziennikarstwem” - mówi jeden z czynnych biografów. „Nie jest literaturą faktu, ale pozostaje w jej obrębie. Odrzucam utożsamienie literatury faktu $\mathrm{z}$ literaturą par excellence. Cezura jest oczywista między kreacją a odtwórczością - ja zajmuję się odtwórczością, komentarzem do literatury" [Kaczorowski 2016: 8]. 
się po prostu do zmiany, to zmiana o określonym znaczeniu, które oceniamy ze względu na to, dzięki czemu żywot zwykły staje się niezwykłym. Ów moment prezentuje się jako splot wątków składających się na jego „decydującość”. Oceny dokonujemy post factum, niekiedy z dużego oddalenia, po ustaniu procesów, które podlegają analizie i ocenie.

Wyznaczenie decydującego momentu wiąże się z krytyczną selekcją faktów oraz dociekaniem ich wewnętrznego znaczenia, a to otwiera drogę do ich (re)konfiguracji. Bez tego otrzymujemy biografie „addytywne” - zbiory ułożonych chronologicznie zdarzeń, opatrzonych biograficzną „konferansjerką”. Praca poświęcona wyznaczeniu decydującego zwrotu w życiorysie pozwala uniknąć porządkowania zdarzeń ignorującego specyfikę konkretnego życia, co wyraża się w jego podziale na narzucane z zewnątrz etapy: dom rodzinny (genealogia), czasy szkolne, okres studiów... ${ }^{11}$. Otwiera natomiast możliwość wyznaczania faz biografii według rytmu indywidualnej egzystencji. Na tej drodze chronologia podporządkowuje się dynamice życia właściwej konkretnej osobie. Jej odsłonięcie traktuję jako najciekawsze, ale i najbardziej ryzykowne wyzwanie dla biografa.

2.

W tej części tekstu zaprezentuję fragment biografii Bobkowskiego, który opracowałem niedawno. Traktuję go jako prototyp wprowadzenia do całości książki. Powstał zgodnie z wyżej przedstawionymi założeniami, a właściwie dochodzenie do nich towarzyszyło pracy nad nim i innymi częściami opracowania, które ciągle jeszcze nie zostało ukończone. Po kilku latach badań, wpierw nad monografią pisarstwa Bobkowskiego, a obecnie nad jego biografią, po dotarciu do mało znanych albo wręcz nieznanych dokumentów, w wydarzeniu, które przedstawiam niżej, upatruję ów decydujący moment. Dopowiem, że nie traktuję go jako wyizolowanego epizodu. Owszem, w centrum znajduje się pewien konkretny przez biografa „prawdziwego nurtu życia [jego - M.N.] bohatera”. 
wypadek, jednak rozumiany zarazem jako kulminacja i zwrot, szczyt i przełom, koniec i początek. Przy czym samo usytuowanie w książce przedstawionego tu fragmentu biografii nie stanowi wyłącznie kwestii artystycznej kompozycji. Zgadzam się bowiem z Hermioną Lee [2009: 125], która po analizie kilku początkowych fragmentów różnych życiorysów zauważyła: „W każdym z tych przypadków - i w każdym, który weźmie się do ręki - początek ustawia całe podejście do tematu. I będzie się ono różnić w zależności od niego".

\section{Ucieczka}

Zacznijmy od cytatu z listu wysłanego z Paryża 29 marca 1939 roku:

Dopiero rano obudziłem się w Poznaniu - było jeszcze szaro. Powoli budziliśmy się wszyscy. Już był dzień na dobre, kiedy zbliżaliśmy się do Zbąszynia, a raczej do ostatniej stacji przed Zbąszyniem. [Bobkowski 1939]

Tego ranka życie Bobkowskiego definitywnie przełamało się na dwie części, które nigdy się ze sobą nie zrosły. Podróżował niemało wcześniej i będzie podróżowal później. Przeniesie się nawet na inny kontynent, do nikomu nieznanej Gwatemali. Jednak w tej chwili już od kilkunastu godzin po prostu uciekał. Niemniej była to ucieczka przygotowana, poprzedzona rodzinną naradą i przez rodzinę zaaranżowana. Przez Tę rodzinę! Stryj Aleksander Bobkowski, wiceminister komunikacji, a - co może w tym przypadku ważniejsze - zięć prezydenta Ignacego Mościckiego, wiedział, do kogo się zwrócić, aby Andrzej z Barbarą bez przeszkód mogli opuścić II RP i żeby po zatrudnieniu bratanka we Wspólnocie Interesów Górniczo-Hutniczych w Katowicach nie został żaden ślad. Poradził mu także, aby list do prokuratora wrzucił dopiero na dworcu w Berlinie. Odbywało się to przy życzliwym milczeniu samego Ministra Sprawiedliwości, który został we wszystko wprowadzony. Zapewne z tego powodu wydanie młodym paszportów trwało jedynie dobę. Pomimo stałego zameldowania w Katowicach zajęło się tym starostwo śródmiejskie w Warszawie. Był 
wtorek 14 marca. Następnego dnia uciekinierzy odwiedzili Dom Bankowy Józefa Skowronka, w którym zaopatrzyli się w potrzebną walutę, no i wreszcie wsiedli do pociągu. W piątek 17 marca otrzymali pierwsze pozwolenie na pobyt we Francji. Dokument będzie przedłużany aż do wybuchu wojny. Wyjeżdżali w dużym pośpiechu, zabrawszy jedynie niezbędne przedmioty. Stąd już po paru dniach Barbara prosiła swoją siostrę, Annę Seifert, o udanie się do opuszczonego katowickiego mieszkania i zabranie stamtąd lżejszych ubrań, a następnie wysłanie ich do Paryża. Tego roku wiosna nad Sekwaną zjawiła się o czasie.

Bobkowski rankiem 16 marca 1939 roku przekroczył w Zbąszyniu nie tylko granicę oddzielającą Polskę od Niemiec, ale także tę oddzielającą chłopca od mężczyzny, dobrze ustawionego członka sanacyjnej elity od faceta mogącego liczyć tylko na siebie, pupilka Rydza-Śmigłego od właściciela jednoosobowej pralni, wreszcie Dziuka od Andrzeja. „Chciałem być czymś, byłem na najlepszej drodze, i nagle jestem niczym. To okropnie boli - i tyle innych rzeczy" [Bobkowski 1939]. Pisał w tym samym liście, jednym z pierwszych wysłanych po ucieczce. Dojmującą prawdziwość tych słów potwierdza, życzliwie podsunięty mu w Paryżu, pomysł zmiany nazwiska, który przyjął ze zrozumieniem. Na szczęście okazało się to niepotrzebne.

W późniejszych latach będzie przekonywał siebie i innych, że nie miał innego wyjścia, że właściwie dobrze się stało, gdyż jak pisał w ostatnim tekście ogłoszonym w „Kulturze”: „Są takie natury, które przejście od młodości do lat dojrzałych muszą załatwić jakimś bezsensownym krachem, w czym dopiero naprawdę odnajdują siebie" [Bobkowski 1960: 25]. Po latach rodzinna katastrofa uległa więc racjonalizacji. Zaczęło się to dużo wcześniej, bo słowa o odnajdywaniu siebie są autocytatem z dziennika prowadzonego w latach 1939-1946. Możemy w nim uchwycić wczesny etap procesu usprawiedliwiania podjętych decyzji. Ucieczka, jej okoliczności i skutki wracać będą w wypowiedziach Bobkowskiego przez całe późniejsze życie. Teraz, we środę 15 marca 1939 roku, po prostu umykal przed polskim wymiarem sprawiedliwości, kryty przez odpowiednio skoligaconych członków rodziny i znajomych. 
Prawdę mówiąc, dla właściwego oszacowania tego, co się wydarzyło, ważniejsze są skutki od przyczyn. Chcę przez to powiedzieć, że choć do dziś trudno z całkowitą pewnością ustalić, co takiego Bobkowski zrobił - czy był zamieszany w aferę finansową (defraudację sporej sumy pieniędzy), czy ujawnił jakieś tajemnice gospodarcze stronie niemieckiej, czy jeszcze coś innego - to właśnie konsekwencje tego zdarzenia zaciążyły na całym jego późniejszym życiu. Zaraz po ujawnieniu afery sugerowano mu popełnienie honorowego samobójstwa, jak po latach zdradził Kazimierzowi Wierzyńskiemu. Możemy śmiało domniemywać, że tego rodzaju propozycji nie składa się komuś, kto zrobił „jakiś głupi żart wobec kolegi z pracy”, jak przedstawia rzecz Joanna Podolska [2013: 25].

Wyjechał na zawsze - nie zobaczy już ojca, który umrze w roku 1945, ani matki, która przeżyje syna o sześć lat. Gdy czytamy w jednym z listów, że jesienią 1956 roku, czyli na pięć lat przed własnym odejściem, prawdopodobnie po raz ostatni rozmawiał z nią przez telefon, wzruszenie ściska nam gardło.

Ten pośpieszny wyjazd, odbywający się w fatalnej atmosferze skandalu, mimo wszystko przekraczającego grono najbliższych, zadecydował o losie przyszłego autora Szkiców piórkiem. Oczywiście przyłożyło do tego swoje ręce wcale liczne grono polityków i wojskowych, z Hitlerem i Stalinem na czele. Historia właśnie wchodziła w kolejny śmiertelny wiraż. A jednak gdyby nie ucieczka, prawdopodobnie nie byłoby powrotu Bobkowskiego do pisania, które obumarło wraz z otrzymaniem przez niego posady urzędnika w ówczesnej spółce skarbu państwa. Natomiast po dotarciu do Francji wpierw powstał obszerny zbiór listów, krążących między Paryżem a Krakowem, fascynujących, stopniowo przybierających postać obszernych i barwnych sprawozdań z tych niby-wakacji. Kontynuacją tej wymiany będzie seria korespondencji z Paryża już okupowanego. Przede wszystkim nie powstałoby jednak kilkanaście zeszytów dziennika, którego przyrastanie okazało się dla autora zarówno szkołą twórczego pisania, coraz bardziej samodzielnego myślenia, jak i systematycznego dojrzewania. Nie byłoby wielu innych zdarzeń, jak bywanie po Wrześniu w ambasadzie polskiej i nawiązanie znajomości z ważnymi postaciami życia 
kulturalnego emigracji, jak ewakuacja na południe Francji, która dała niepowtarzalną okazję do naocznego poznania kraju i jego mieszkańców. Jeszcze później nie byłoby spotkań z Józefem Czapskim, Gustawem Herlingiem-Grudzińskim, i osobą najważniejszą dla pisarstwa Bobkowskiego, czyli Jerzym Giedroyciem. A czy gdyby nie ten wyjazd, przetrwałoby niedawno zawarte małżeństwo z Basią? Ucieczka stała się okazją do uwolnienia od rodziny Andrzeja, która przyjęła ich związek z wyniosłym chłodem. Ślub zawarty w grudniu 1938 roku był bardziej niż skromny. „Nie było wesela. Nawet nie było większej uroczystości. Nie dostąpiliśmy zaszczytu zaproszenia na obiad. Dla rodziny Bobkowskich to był mezalians" [Stawska 2013: 21] - wspominała po latach siostra panny młodej. Czy Andrzej miałby tyle samozaparcia, aby wiernie trwać przy Basi, znosząc niechęć rodziny i opierając się gronu krakowskich i warszawskich znajomych ze swojej sfery?

Wydobywam pozytywne skutki ucieczki, wskazuję na znaczenie całej sprawy dla literatury, ale przecież były to skutki uboczne, nieplanowane, niespodziewane ${ }^{12}$. Bo wyjazd miał być wpierw po prostu zniknięciem z pola widzenia, aż do wyciszenia skandalu. Po kilku dniach od przybycia Bobkowskich do Paryża pojawiła się szansa na szczęśliwy finał całej afery. Cytowany już list z 29 marca 1939 roku kończy, dopisana ołówkiem przez Barbarę, informacja: „Napiszemy dokładniej o tej całej sprawie, cóż, nie ma się co namyślać, to cud istny to wszystko, co się stało, i to, że J[ędrek] może się zrehabilitować w swojej firmie" [Bobkowski 1939]. Bobkowski miał kontynuować pracę w przedstawicielstwie Syndykatu Polskich Hut Żelaznych w Buenos Aires. 5 kwietnia otrzymał w polskim Konsulacie Generalnym wpis w paszporcie, potwierdzający ważność dokumentu na wyjazd do Argentyny. Wpływy stryja Aleksandra nadal sięgały daleko, lecz tym razem wola kogoś innego ujawniła ich granice. Bobkowscy zostali na lądzie do czerwca 1948 roku. Rejs przez Atlantyk wieńczyłby sukcesem akcję ucieczki,

Sam Bobkowski jako decydujący moment swojej biografii wykreował narodziny siebie jako pisarza. Stanowily one element jego prywatnej mitologii przedstawionej w Szkicach piórkiem. Myślę o dopisanym po latach, nieistniejącym w oryginalnym dzienniku, fragmencie Szkiców... z 12 czerwca 1940 roku [zob. Nowak 2014: 35-36]. 
byłby także spełnieniem ich osobistych marzeń. Fiasko dało literaturze polskiej jednego $\mathrm{z}$ najbardziej oryginalnych jej twórców.

Splot indywidualnych wyborów z decyzjami urzędników i wolą mężów stanu sprawił, że wyjazd Andrzeja i Barbary z Polski okazał się definitywny. I być może banalne francuskie powiedzenie, że wyjechać, to trochę jakby umrzeć, okazało się boleśnie prawdziwe.

\section{Bibliografia}

Arendt Hannah (2010), Kondycja ludzka, przeł. Anna Łagodzka, Aletheia, Warszawa.

Bobkowski Andrzej (1932), Dziennik, archiwum prywatne Małgorzaty

Czerwińskiej-Miklaszewskiej, zapis z dnia 4 października.

Bobkowski Andrzej [pseud. Bob] (1935), W parku frakowym, „Tempo

Dnia”, nr 63, s. 3

Bobkowski Andrzej (1939), List do Anny Seifert, 29 marca, IBL PAN, Rps. Zb.W1. 227.

Bobkowski Andrzej (1948a), List, „Kultura”, nr 9-10, s. 3-11.

Bobkowski Andrzej (1948b), Pożegnanie, „Kultura”, nr 6, s. 82-93.

Bobkowski Andrzej (1950), Święta w Gwatemali [dział: „Listy do redakcji”], „Tygodnik Powszechny”, nr 53, s. 6.

Bobkowski Andrzej (1960), Biografia wielkiego Kosmopolaka, „Kultura”, nr 9, s. 19-32.

Clifford James L. (1978), Zbieranie materiałów, w: tegoż, Od kamyków do mozaiki. Zagadnienia biografii literackiej, przeł. Anna Mysłowska, Czytelnik, Warszawa, s. 11-89.

Goffman Erving (2008), Człowiek $w$ teatrze życia codziennego, przel. Helena Datner-Śpiewak i Paweł Śpiewak, Aletheia, Warszawa.

Gray Christopher (2003), Streetscapes/ The Regent Family Residence for the Homeless, Formerly the Broadway View, at 104th Street and Broadway; A Once-Grand Hotel Gets a Socially Conscious Icon [online], [dostęp: 4 października 2018], https://www.nytimes. $\mathrm{com} / 2003 / 08 / 31 /$ realestate/streetscapes-regent-family-residencefor-homeless-formerly-broadway-view-104th.html.

Hamilton Nigel (2017), Biography as Corrective, w: The Biographical Turn. Lives in History, red. Hans Renders, Binne de Haan, Jonne Harmsma, Routledge, New York [USA]. 
Hoberman Ruth (2001), Biography: General Survey, w: Encyclopedia of Life Writing. Autobiographical and Biographical Forms, vol. 1, red. Margaretta Jolly, Fitzroy Dearborn Publishers, Chicago [USA].

Holmes Richard (2011), Footsteps. Adventure of a Romantic Biographer, Harper Press, London [Wielka Brytania].

Holmes Richard (2017), This Long Pursuit. Reflections of a Romantic Biographer, William Collins, London [Wielka Brytania].

Johnson Samuel (1750), The Rambler, 60 (October 13); cyt. za: Hamilton Nigel (2012), How to do Biography. A Primer, Harvard University Press, Cambridge, Massachusetts [USA].

Kaczorowski Aleksander (2016), Czeski los. Z Aleksandrem Kaczorowskim rozmawia Agnieszka Papieska, „Nowe Książki”, nr 1, s. 4-9.

Lee Hermione (2009), Biography. A Very Short Introduction, Oxford University Press, New York [USA].

Nadel Ira Bruce (1984), Biography. Fiction, Fact and Form, St. Martin's Press, New York [USA].

Nowak Maciej (2014), Na tuku elektrycznym. O pisaniu Andrzeja Bobkowskiego, Biblioteka „Więzi”, Warszawa.

Podolska Joanna (2013), Wstęp, w: Andrzej Bobkowski, Listy do Aleksandra Bobkowskiego 1940-1961, oprac. Joanna Podolska, Biblioteka „Więzi”, Warszawa.

Stawska Maria (2013), cyt. za: Podolska Joanna, red. (2013), Bobkowski. Chuligan wolności [katalog wystawy], Centrum Dialogu im. Marka Edelmana w Łodzi, Łódź.

Theroux Paul (2017), Gtębokie potudnie. Cztery pory roku na głuchej prowincji, przeł. Michał Szczubiałka, Wydawnictwo Czarne, Wołowiec.

Woolf Virginia (2015), Sztuka biografii, w: Eseje wybrane, przeł. Magda Heydel, oprac. Magda Heydel, Roma Sendyka, Karakter, Kraków, s. 315-322.

\section{Maciej Nowak}

\section{The decisive moment. Around the biography of Andrzej Bobkowski}

The article consists of two short parts. The first part explores rather theoretical problems chosen by the author during his current work. Among them is the titular problem - the crucial moment in somebody's life, with all its consequences. The second part contains the opening excerpt from Bobkowski's biography recently written by the author. According to the researcher, it sets up the biographer's tone and the whole approach to the subject. This initial part of the upcoming book entitled The Escape is 


\section{MACIEJ NOWAK}

an example of the implementation of the 'decisive moment' concept in practice.

Keywords: biography - research - methodology; biography as a literary form; Andrzej Bobkowski's life.

Maciej Nowak - doktor habilitowany, historyk literatury, edytor, krytyk. Autor monografii Na łuku elektrycznym. O pisaniu Andrzeja Bobkowskiego (2014). Opracował i wydał pierwszy odczytany z rękopisu dziennik Bobkowskiego (Notatnik 1947-1960, 2013). Autor studiów poświęconych dziennikom polskich pisarzy nowoczesnych, m.in. Pamiętnikowi Stanisława Brzozowskiego i Dziennikowi okupacyjnemu Stanisława Rembeka. Opublikował cykl rozpraw dotyczących epistolografii Zbigniewa Herberta. Znawca twórczości Hanny Malewskiej, Jana Lechonia, Zygmunta Haupta, a także problematyki badań nad sacrum w literaturze. Obecnie pracuje nad biografią Andrzeja Bobkowskiego. Adres e-mail: maciej.nowak@kul.lublin.pl. 